\title{
The occurrence of anglicisms in the Czech and Slovak lexicons
}

\author{
Gabriela Entlova - Eva Mala
}

DOI: 10.18355/XL.2020.13.02.11

\begin{abstract}
In the study, Anglicisms are presented by a brief analysis of their adaptation to the Czech and Slovak orthographic, phonological and morphological systems as well as their semantic peculiarities. The individual areas of interest in Anglicisms, including their linguistic background and basic information on taking over new lexical items are also reflected in the paper. The trend to adopt Anglicisms has been continuing up to the present day and concerns all areas of social life, mainly because English serves as a global lingua franca.
\end{abstract}

Key words: Anglicism, adaptation, linguistic levels, Czech, Slovak

\section{Introduction}

Incorporating new words termed as Anglicisms (English borrowings) is one of the most productive ways of any modern language vocabulary enrichment. It is an important necessity also for Slavic languages to enlarge their lexicons as this process requires denotation of the actual and constantly changing reality. In this respect, opinions from a number of Czech and Slovak linguists differ in certain aspects concerning the suitability of the use of Anglicisms in particular contexts, but they share some similar ideas related to the aptness of their usage (see Sochova Postolkova, 1994; Srpova, 2001; Svobodova, 2007; Mistrik, 1999; Masar 1994; Oravcova, 1994; Povazaj, 1994). A lot of Anglicisms are unambiguous, apt, and internationally comprehensible, not laden with any secondary meaning. Such borrowings contribute to the vocabulary of the recipient language where there is no corresponding domestic equivalent and hold an advantage due to their international character and language economy. In this study, the term Anglicism is understood as suggested by Gorlach: "An Anglicism is a word or idiom that is recognizably English in its form (spelling, pronunciation, morphology, or at least one of the three), but is accepted as an item in the vocabulary of the receptor language" (Gorlach 1994: 239). The study provides an overview of the research results based on the analysis of more than a thousand of Anglicisms conducted by their authors. It presents a comparison of similarities and dissimilarities of English words that have infiltrated into the Czech and Slovak languages through mass media, literature, film, or direct contact between the Czech and Slovak citizens and the English speaking ones. The data for the analysis of Anglicisms were also taken from dictionaries, relevant printed publications, and electronic sources. Relations between different grammar phenomena were specified by the method of synthesis and the method of theoretical analysis comprising induction, deduction, confrontation, and generalization. The research sample included Anglicisms in Czech and Slovak, no matter if they are of English origin or from languages they were taken over into the English lexicon. In the process of its development, English has borrowed and adapted a number of words from other languages, but Czech and Slovak took them over from the English language, and most of them have become internationalisms.

Due to the fact that Czech and Slovak belong to the West-Slavic branch of European languages, a number of similarities can be found in their grammatical structures and in their lexicons, and the occurred dissimilarities just represent the uniqueness of the two otherwise related languages. It also concerns the process of borrowing of English words of which an insight is given in this study. Although the Czech and Slovak 
language systems allow the creation of words of domestic origin, the English language enriches them in cases where there is a need for the names of new objects, concepts, or phenomena. Thus Anglicisms contribute to the spread of cultural beliefs and social activities from one group of people to another. Through the cultural diffusion mediated by the use of languages enriched with borrowings, horizons are broadened and people become more culturally rich.

\section{The phonetic-phonological level of adaptation}

The research is focused on the category of nouns, as it forms by far the most numerous category of Anglicisms in Czech and Slovak. The nouns have been entering the designated languages mostly in the written forms, although a number of oral transfers are documented, too. The process of borrowing of English lexical units is connected with their partial or total adaptation to the orthographic, phonetic, and grammatical standards of the receiving languages. The degree of adaptation often depends on the length of time the English words have been used. A large amount of the Anglicisms found in the Czech (Entlova, 2014) and Slovak (Mala, 2003) lexicons occur in the lexical-semantic group of sports terminology, names of games, and activities:

- $\quad$ orthographically unadapted lexical units in both Czech and Slovak, e.g., allstar game, bodybuilding, bowling, bungee-jumping, carving, fair-play, fitness, golf, jogging, Nordic walking, paintball, paragliding, play-off, power-lifting, power-play, rafting, ring, rugby, set, skibob, ski-park, snowboarding, spinning, squash, steeplechase, stepper, streetball, tiebreak, time-out, tip, touchdown, windsurfing, wrestling;

- $\quad$ adapted lexical units in both Czech and Slovak, e.g. aut (< out), bejzbal (< baseball), bekhend (< backhand), bodyček (< body check), box (< boxing), faul (< foul), finále (< finals), finiš (< finish), forhend (< forehand), gól $(<$ goal), hokej (< hockey), jachting (< yachting), knokaut (< knockout), kriket (< cricket), krosček / krošček (< crosscheck), mečbol / mečbal (< match ball), ofsajd (< offside), penalta (< penalty), skreč (< scratch), tým / tím $(<$ team), tenis ( $<$ tennis), volejbal ( $<$ volleyball).

Many of the new lexical items are adapted phonetically, i.e., with partial original English pronunciation and partial spelling changes. Anglicisms in Czech and Slovak often take over an orthographic form equal or similar to the English phonetic form, e.g., the consonant -j- (in: jazz, jeep, job, juice) pronounced [dz] in English is transcribed as -dž- into Czech and Slovak thus giving the graphical forms: $d \check{z} e z, d z ̌ i p$, $d z ̌ o b$, or $d \check{z} u s$ / džús. The English grapheme -c- is spelled and pronounced [k] in Czech and Slovak, e.g. kánoe / kanoe (< canoe), kouč (< couch), kraul (< crawl). The English phonemes [J] and [t $\left.\int\right]$ are orthographically expressed as -š- and -č- in Czech and Slovak, with their simplified pronunciation symbols $/ \check{\mathrm{s}} /, / \mathrm{c} /$, e.g., šortky (< shorts), šunt (< shunt), punč (< punch), sendvič (< sandwich).

The significant differences within the phonemic systems can be seen in the absence of English phonemes $[\theta, \partial, w, y, æ, ~ ə]$ in Czech and Slovak. The missing phonemes are substituted with those which correspond with the original English pronunciation the most, e.g., the English [æ] is substituted either with -e-, e.g., džem, or with -a-, e.g., manažment. The English final [ə] in words, such as pullover, speaker, scooter, has different orthographic and phonemic forms in Slovak and Czech, i.e., er [er]: pulóver, spiker, skúter in Slovak, but -r [r]: pulovr, spikr, skútr in Czech. The final -ing form in words, such as meeting, screening, stretching, pronounced with [y] in English is

XLinguae, Volume 13 Issue 2, April 2020, ISSN 1337-8384, ISSN 2453-711X 
spelled in the same way (miting, skrining, strečing) in Slovak but (mitink, skrinink, strečink) in Czech with the pronunciation of the final $-\mathrm{g}$ either $[\mathrm{g}]$ or $[\mathrm{k}]$ often depending on the voiced or voiceless consonant of the following word in both, Czech and Slovak languages. The English phoneme $[\theta]$ is mostly substituted with $/ \mathrm{t} / \mathrm{in}$ Czech and Slovak, e.g. thriller / triler ( $<$ thriller), the phoneme $[w]$ is replaced with [v], e.g. vikend (< weekend), software / softvér (< software). Neither the Czech nor Slovak phonemes $[\mathrm{p}, \mathrm{t}, \mathrm{k}]$ are aspirated as opposed to the English $[\mathrm{p}, \mathrm{t}, \mathrm{k}]$ at the beginning of a stressed syllable.

During the process of adaptation of English words into Czech and Slovak it happens that both forms, i.e. non-adapted and adapted, occur side by side in the lexicon, e.g. casting - kástink / kasting, club - klub, designer - designér / dizajner, dressing dresink / dresing, fair - fér, gentleman - džentlmen, hattrick - hetrik, houseboat hausbót, jazzman - džezmen, make-up - mejkap, sitcom - sitkom, sprayer - sprejer, tweed - tvid.

The above analysis of Anglicisms in Czech and Slovak demonstrates that their sound structure includes elements of the phonetic and orthographic composition of the underlying English word. It is thus possible to make a distinction between phonetically or orthographically adapted Anglicisms.

\section{The morpho-syntactic level of adaptation}

The contemporary English language belongs to the analytical group of languages, while Czech and Slovak to the synthetic (inflectional) one. Nouns borrowed from English acquire those grammatical categories which function in word classes of the target languages. The criteria on the basis of which domestication of Anglicisms is determined include not only the complete semantic autonomy of words but also the ability to create lexical-semantic microsystems of words, e.g., phraseological units, metaphorical and metonymical extensions, as well as active lexical word-formation that often leads to the development of new lexemes, their inflectional character and their employment in common source languages allowing them to conjugate verbs and decline nouns, adjectives, and pronouns according to the Czech and Slovak paradigms.

Most Anglicisms are characteristic for their ability to form derivatives, e.g. adjectives - by adding adjectival morphemes to the nouns, e.g. bluesový, grilovaný, hokejový, holdingový, interfejsový, internetový, kovbojský, parkovací, softbalový, rokenrolový, manšestrový / menčestrový, skautský, slangový, snobský, sportovni / športový, stresujici / stresujúci, strečový, striptýzový / striptizový, swingový, tenisový, trendový, tuningový, trampský, trempský / trampský, webový, westernový; or verbs - by adding infinitive suffixes (-ovat in Czech / -ovat' in Slovak) to the word bases, e.g. Czech: esemeskovat, faulovat, importovat, parkovat, resetovat, skenovat, surfovat, trénovat; Slovak: esemeskovat', faulovat', importovat', parkovat', resetovat', skenovat', surfovat', trénovat'.

Alongside the declinable nouns there also exist indeclinable, orthographically unadapted Anglicisms, e.g. brandy, check-in, derby, graffiti, lady, miss, rely, knowhow, play-off, puzzle, sci-fi, science fiction, (talk) show, selfie, whisky.

Out of the total number of analyzed Anglicisms, more than $50 \%$ form nouns of the masculine gender in Czech and Slovak. To this category belong nouns that end in a consonant, e.g. barter, biftek, bigl, buldok / buldog, gangster, gin, gril, hit, harassment, horor, hostel, chuligán, kurzor, kvaker, koktejl, kombajn, kovboj, motel, nylon, outfit, roadster, sejf, server, setter, slang, smog, squatter, stevard / steward, toner, truck, workshop; including the -ing form, e.g., babysitting, bodybuilding, brainstorming, casting, catering, cracking, doping, e-learning, facelifting, homebanking, marketing, modeling, podcasting, roaming, teambuilding, teleshopping, timing, wellness, workoholik. 
The group of nouns of the feminine gender consists of Anglicisms that end in a vowel -a in Slovak, e.g. coca-cola, doga, gorila, kólia, ustrica, and in -a or -e in Czech, e.g. coca-cola, doga, gorila, kolie, ústřice; in Czech and Slovak also the suffix -ka denoting the feminine gender-shift, e.g. inženýrka / inžinierka, manažerka / manažérka, raftařka / raftérka, sprinterka / šprintérka, stevardka.

A group of neuter gender deverbatives consists of Anglicisms containing the suffix ství in Czech and -stvo in Slovak, e.g. dealerství / dilerstvo, hackerstvi / hekerstvo, leadership / líderstvo, lordství / lordstvo, chuligánství / chuligánstvo, sponzorství / sponzorstvo; and noun derivatives ending in -ování in Czech and -anie in Slovak which have replaced the original English -ing form, e.g. dabováni / dabovanie (< dubbing), gamblování / gamblovanie (< gambling), kempování / kempovanie (< camping), lobováni / lobovanie (< lobbing), monitorováni / monitorovanie (< monitoring), skenování / skenovanie (< scanning), surfování / surfovanie (< surfing), trénováni / trénovanie ( $<$ training).

Derivation belongs to the most productive word-formation processes that are also evident in the group of Anglicisms in Czech and Slovak. Nouns of the masculine gender contain the suffix -ista, e.g. lobbista / lobista, folklorista, chartista, humorista, rasista, stylista / štylista, including the names for men performing sports, e.g. cyklista, hokejista, kanoista, volejbalista, ragbista, tenista. The other Czech and Slovak examples of masculine nouns that were taken over from English with their original English suffixes are, e.g. blogger / bloger (< blogger), developer / developér $(<$ developer), dispečer (< dispatcher), distributor / distribútor (< distributor), designer / dizajner (< designer), driblér (< dribbler), investor (< investor), manažer / manažér $(<$ manager), outsider (< outsider), sprinter / šprintér (< sprinter), rocker / roker $(<$ rocker). Some English nouns contain the -man element expressing the masculine gender which is transferred into Czech and Slovak either in the form of -men, e.g. businessman / biznismen, džentlmen, džezmen, šoumen, or -man, e.g. erotoman, narkoman, ombudsman, superman. Another suffix denoting the masculine gender of Anglicisms in Czech and Slovak is -ismus / -izmus, e.g. feminismus / feminizmus, lobismus / lobizmus, rasismus / rasizmus, sexismus / sexizmus, thatcherismus / thatcherizmus. Czech and Slovak abstract nouns of the feminine gender may be formed by suffixes added to English borrowings, e.g. -ace/-ácia: globalizace / globalizácia. -ie/-ia: narkomanie / narkománia. English nouns often take over international prefixes, and, subsequently, such a word form infiltrates into Czech and Slovak, e.g. debriefing / debrifing, inkorporace / inkorporácia, restart / reštart, transakce / transakcia. Both a prefix and suffix may be found in Anglicisms such as: dekódování / dekódovanie, nelobování / nelobovanie, reinvestice / reinvestícia.

To the English words (chip, clip, cake) taken over in their original plural ending (chips, clips, cakes), the Czech and Slovak plural ending was added in order to eliminate the discrepancy between the content and form of these words thus to express the differences between the singular (čips, klips, keks) and the plural: čipsy, klipsy, $k e k s y$. A similar process is found in English pluralia tantum nouns (leggings, jeans) to which the plural ending -y was added after their entering the Czech and Slovak vocabulary thus giving the forms: legínsy, džinsy, as well as: leginy, džiny. In case of English shorts the ending -ky was added in Czech and Slovak: šortky.

As presented above, Czech and Slovak demonstrate their language closeness by numerous similarities in their grammatical structure also in the field of Anglicisms. The results of the morphological analysis show that nouns borrowed from the English language submit themselves to the grammatical categories proper to this word class in Czech and Slovak, i.e., they acquire the categories of number, gender, and case. Most Anglicisms are inflected in Czech and Slovak, only a few of them belong to the nondeclinable group of borrowings. The gender is determined by formal features of the 
word following the Czech and Slovak grammar rules. Anglicisms are usually adopted in the singular number.

A further step is taken when Anglicisms, in their turn, participate actively in the formation of new words. The derivational processes take place mainly through suffixation, less through prefixation. English nominal compounds and phrases, more or less adapted, have also entered the lexicons of Czech and Slovak languages, e.g., after party, airbag, arm-wrestling, baby-boom, backstage, bestseller, big band, billboard, Black Jack, bodyguard, bookmaker, brain-drain, clip maker, copyright, deadline, double-decker, drive-in, duty-free shop, fanklub, garden-party, hard rock, hotdog, jackpot, mainstream, pen club, penthouse, playback, playboy, playgirl, power-point, public relations, rooming-in, science fiction, second-hand, sex appeal, sex-shop, showroom, ski park, soundtrack, talk show, top model, trade mark, and others. The Czech and Slovak languages have borrowed internationally recognized abbreviations and acronyms, such as: EFTA (European Free Trade Association), ISDN (Integrated Services Digital Network), ISO (International Standard Organization), MS DOS (Microsoft Disk Operation System), NATO (North Atlantic Treaty Organization), OPEC (Organization of Petroleum Exporting Countries), ROM (Read Only Memory), USB (Universal Serial Bus), VIP (very important person), WHO (World Health Organization), www (world wide web), and many others.

\section{The lexical-semantic level of adaptation}

Anglicized neologisms are domesticated words adapted on different levels to the Czech and Slovak language systems and, gradually, become part of the neutral vocabulary. Fully domesticated lexical units that are no longer felt to be foreign describe common reality, and their orthographic, grammatical, lexical, or stylistic usage does not cause any problems for Czech or Slovak native speakers.

Some Anglicisms may move from one specialized field into another and become less specific as their meaning broadens and shifts, e.g., in Czech, there is an Anglicism farmár (in Slovak farmár), a word that originally denotes a person who owns or manages a farm. It takes on a new meaning under the influence of a foreign model, so today it also designates an NHL farm team hockey player. Following Vachek's opinion that "... the language system does not accept such external interventions that would be in contrast with its internal demands" (Vachek 1962: 45) we can assume that Anglicisms of terminological character in the Czech and Slovak languages (alongside with their purely domestic designations) will remain an indispensable part of the lexicons primarily due to their unambiguous and international character. The following examples may prove the above statement:

The English word goal has three meanings (see Collins Online Dictionary). Nevertheless, it is reduced to only one meaning in Czech and Slovak chiefly relating to the scoring of points in football, hockey, or in other games. The monosyllabic Anglicism orthographically simplified in Czech and Slovak as gól, is much better suited for its emotive use (e.g., by shouting fans) than the Czech disyllabic word branka. The Anglicism gól and its domestic Czech equivalent branka represent synonyms. Similarly, the Anglicism fotbal (in Slovak futbal) and its purely Czech designation kopaná for English football are used for fine differentiation of stylistically marked context.

Some modifications which the Czech and Slovak vocabularies are going through nowadays can be characterized by certain tendencies towards internationalization and simplification of their lexicon. On the one hand, and the fact that the technical terms also enter the common vocabulary on the other. Anglicisms often express such notions that Czech and Slovak's words are not able to term. It is of great importance, particularly in specialized fields in which technical and scientific terms should be monosemantic, and inadequate Czech and Slovak equivalents may have undesirable 
shades of meaning. It is difficult to analyze all Anglicisms, or even a greater part of them in the inspected languages, however, an insight is given into this dynamic and constantly changing reality, namely Anglicisms that function in the field of information technology and computing:

- unadapted lexical units in both Czech and Slovak, e.g., blue-ray, Bluetooth, desktop, e-learning, enter, google, hands-free, hard disk, hardware (also hardvér in Slovak), iBook, input, internet, iPod, joystick, keyboard, login, memory, monitor, network, notebook, offline, online, pixel, PlayStation, podcast, port, printer, setting, setup, skype, software (also softvér in Slovak), spam, subwoofer, touchpad, wafer, web, webzine, zoom;

- $\quad$ adapted lexical units in both Czech and Slovak, e.g. bajt $(<$ byte), čet $(<$ chat), čip (< chip), displej (< display), drajv (< drive), interfejs (< interface), mejl (< mail), ploter $(<$ plotter), procesor (< processor), skener $(<$ scanner), skrining (< screening), videorekordér (< videorecorder), webkamera ( $<$ web camera).

Among the three groups of loanwords, i.e. (i) inflexible, un-adapted English expressions, i.e., words in their original English spelling, pronunciation, and morphological adaptation are only partial, e.g., cheerleaders, (ii) adapted loanwords, i.e. adapted on the morphological level with the original spelling and, in part, their pronunciation, e.g. Czech: flipovat, and (iii) calques, i.e., new lexical items created in the target language through translation, e.g. Czech: príliš mnoho hráčù na ledové ploše (< too many men on the ice), there exist certain intermediary stages which move from one language system to another, from the centre to the periphery and from the periphery to the centre of the language system (Entlova 2014). The calques occur in all fields of social life, e.g. Czech: pamět', otevřrený systém and Slovak: pamät', otvorený systém (< memory, open system), Czech and Slovak: počitač (< computer), Czech: horské kolo and Slovak: horský bicykel (< mountain bike), Czech: žlutá karta, červená karta and Slovak: žltá karta, červená karta (< yellow card, red card), Czech: vymývání mozkỉ, Slovak: vymývanie mozgov (< brain-washing), Czech and Slovak: mrakodrap (< skyscraper), and others. A recent example of a semantic calque from the field of information technology occurring in both Czech and Slovak lexicon is mys ( $<$ mouse) originally meaning rodent but which has acquired a new meaning denoting a computer control device.

Lexical differences between Anglicisms and their source words include a semantic reduction, on the one hand, i.e., the polysemantic word in the source language is reduced to only one meaning in the receiver language, e.g., gól (< goal, see above), and semantic narrowing on the other, i.e., a regular semantic change from a general meaning of the source word to a specific one in the receiver language, e.g. the general deverbal sense of the English meeting understood as 'an occasion when people come together' was narrowed to either company or a political rally or sports event in Czech. Nevertheless, the opposite semantic development, i.e., semantic widening of individual meanings of Anglicisms in comparison to the semantics of its English etymon, is also documented in the Czech and Slovak languages.

Anglicisms extended to other meanings are for instance: helikoptéra (< helicopter) originally an aviation term denoting an aircraft has acquired a new meaning in Czech: in freestyle skiing, skateboarding, or also waterskiing it is a $360^{\circ}$ turn performed midair with the body vertical; fitink (< fitting) originally an industrial pipe fitting has a new meaning in Czech: either a golf club fitting or fitting for clothes in the fashion 
industry; in Slovak: an adjustment in computer technology. The meaning of every polysemous word reflects, in a way, a certain part of an extra-linguistic reality. It is determined by its relationship to other words and their meanings and to the collocations they make, i.e., habitual (not random) and meaningful co-occurrences of words within a close context (Entlova, 2014).

Anglicisms that enter the vocabulary of Czech and Slovak languages not only accurately name the new reality but they also bring new cultural attributes alongside with the original denotation so it would not be effective to replace them with their domestic (and sometimes) misleading paraphrases or calques, especially in commercial, economic and financial texts, e.g., franšizing ( $<$ franchising) in Czech is used instead of a wordy paraphrase "udělování licencí k distribuci zboží dané firmy", and frenčajzing in Slovak as "udel'ovanie licencií k distribúcii tovaru danej firmy". Similar examples of Anglicisms in Czech and Slovak are software / softvér (< software), and its Czech appellation: programové vybavení počítače; Slovak appellation: programové vybavenie počítača; hacker / heker (< hacker) - Czech: počítačový zločinec a narušitel počítačových sítí, průnikáŕ (Czech also uses Anglicisms cracker and black hat in similar contexts); Slovak: počítačový podvodník, pirát; summit / samit (< summit) - Czech: setkání nejvyšších představitelů, schůzka na nejvyšší úrovni, Slovak: stretnutie najvyšších predstavitel'ov štátov, schôdzka na najvyššej úrovni; doping (< doping) - Czech: uživání nedovolených povzbuzujících prostředků, and Slovak: užívanie nedovolených povzbudzujúcich prostriedkov. Being compared with their domestic Czech and Slovak multi-word naming units and paraphrases, often ambiguous ones, Anglicisms are shorter and thus more economical in the texts of specialized technical character. The following Anglicisms from the field of economy, administration, or mass media used in Czech and Slovak have also proven their effective usage in practice, e.g., brifink / brifing, byznys / biznis, damping, export, impeachment / impičment, interview, holding, import, clearing / klíring, know-how, leasing/lizing, rating, manažment, marketing.

As the results of our research show, the Czech and Slovak languages adopt identical English terms into their vocabulary. There are, however, some apparent differences where Czech and Slovak retain their domestic naming units over the English ones, for instance, when the Czech language has adopted an Anglicism tramvaj ( $<$ tramway), but the Slovak language did not and prefers its domestic naming unit: električka. An opposite example is the name of the game in Slovak: basketbal (< basketball) while the Czech language, besides the Anglicism basket(bal) also uses a calque: košíková.

During the present-day period of the world pandemic, not only Czechs and Slovaks but also other nations use internationalisms for their communication borrowed from English of which origin are mainly Latin and Greek, e.g. virus (< English: virus < Latin), laborator / laboratórium (< laboratory < Latin), senior (< senior $<$ Latin), testování / testovanie (< testing < Latin), epidemie / epidémia (< epidemic < Greek), krize / kríza (< crises < Greek), pandemie / pandémia (< pandemics < Greek), expert (< expert < Latin), klient (< client < Latin), stabilita (< stability < Latin), stacionár 1 stacionár (< stationary < Latin), gel / gél (< gel < Latin), infekce / infekcia (< infection $<$ Latin).

In general, it may be stated that Anglicisms have spread into all spheres of life within Czech and Slovak society. The development of a society is reflected in numerous lexical units that define social relations and changes that undoubtedly require lexical innovations and transformations in the recipient language. As long as a language can assimilate the linguistic loan, play with it, and shape it so that it becomes integrated in its language system of inflection paradigms, its patterns, and models, Anglicisms are considered beneficial from both the perspective of enriching the vocabularies of the Czech and Slovak languages and the perspective of easier international communication among the language users. 
The study represents a brief inquiry into the occurrence of Anglicisms in the vocabulary of Czech and Slovak languages. As the process of borrowing new terms and their subsequent adaptation in the receiver languages is in continuous progress and development, this current linguistic area to reveal the ways, reasons, and types of Anglicisms still requires further research and analysis in order to contribute further to the development of human society and cultural diffusion.

\section{Bibliographic references}

DURKIN, P. 2014. Borrowed Words: A History of Loanwords in English. OxfordNew York: Oxford University Press. ISBN 97-8019-957-4995

ENTLOVA, G. 2014. The present-day Anglicisms in Czech within the domain of sport. Saarbrücken: Omni Scriptum GmbH \& Co. KG. ISBN-13: 978-3659524417.

GORLACH, M. 1994. A Usage Dictionary of Anglicisms in Selected European Languages. In: International Journal of Lexicography, n. 3, pp 233-46. Oxford: Oxford University Press. ISSN 0950-3846.

HAUGEN, E. 1950. The analysis of linguistic borrowing. In: JSTOR. Available online: https://www.jstor.org/stable/410058.

HOAD, T. F. (ed.). 1993. The Concise Dictionary of English Etymology. OxfordNew York: Oxford University Press. ISBN 0-19-861182-X.

HORECKY, J. - BUZASSYOVA, K. - BOSAK, J. et al. 1989. Dynamika slovnej zasoby sucasnej slovenciny. Bratislava: Veda, ISBN 80-224-0947-5.

IVANOVA-SALINGOVA, M. - MAANIKOVA, Z. 1979. Slovnik cudzich slov. Bratislava: SPN. 67-567-79.

KACALA, J. 2001. Spisovna slovencina v 20. Storočí. Bratislava: VEDA. ISBN $80-$ 224-0666-X.

KRAUS, J. et al. 2007. Novy akademicky slovnik cizich slov. Praha: Academia. ISBN 978-80-200-1415-3

MALA, E. 2002. English borrowings in the Slovak language. In: Zbornik z medzinarodnej vedeckej konferencie CO-MAT-TECH 2002. Trnava: MtF STU, pp. 562565. ISBN 80-227-1768-1

MALA, E. 2003. Vyskyt anglicizmov v sportovej terminologii. In: Zborník z medzinarodnej konferencie Univerzitny sport a telesna vychova na zaciatku 3. tisicrocia. Nitra: UKF, pp. 146-149. ISBN 80-8069-273-4.

MALA, E.. 2005. Anglicizmy v slovnej zasobe slovenskeho a ruskeho jazyka. In: Lingua et communicatio in Sphaera Culturae, pp. 87-92, Ostrava: Ostravská univerzita. ISBN 80-7368-120-X.

MASAR, I. 1997. Terminologicka kultura a komunikativna efektivnost. Available online: http://www.juls.savba.sk/ks/1997/4/ks1997-4.txt.

MISTRIK, J. 1999. Moderna slovencina. Bratislava: SPN. ISBN 80-06-00924-4.

ORAVCOVA, A. 1994. O anglickych slovach v dennej tlaci. Available online: http://www.juls.savb.sk/ks/1994/5/ks1994-5txt.

POVAZAJ, M. 1994. Sucasny stav jazykovej kultury. Available online: http://www.juls.savba.sk/ks/1994/5/ks1994-5.html=s-asn-stav-jazykovej-kultury.

REJZEK, J. 1993. K formalni adaptaci anglicismu. Available online: http://naserec.ujc.cas.cz/archiv.php?art=7106.

REJZEK, J. 2015. Cesky etymologicky slovnik. Voznice: nakladatelství LEDA. ISBN 978-80-7335-393-3.

RAGAN, J. 1998. Anglicko-slovensky slovnik vypoctovej techniky. Bratislava: SPN. ISBN 80-08-01117-3.

SOCHOVA, Z. - POSTOLKOVA, B. 1994. Co v slovnicich nenajdete. Praha: Portál. ISBN 978-7178-000-6.

XLinguae, Volume 13 Issue 2, April 2020, ISSN 1337-8384, ISSN 2453-711X 
SRPOVA, H. 2001. Impakt socialnich faktoru na vyvoj ceskeho lexika konce 20. století. In: Ceský jazyk a literatura na sklonku XX. Století. Wałbrzych: PWSZ, Ostrava: Ostravska univerzita. ISBN 80-7042-587-3.

SVOBODOVA, D. 2007. Internacionalizace soucasne ceske slovni zasoby. Ostrava: Ostravska univerzita. ISBN 978-80-7368-308-5.

VACHEK, J. 1962. K otazce vlivu vnejsich cinitelu na vyvoj jazykoveho systemu. In: Slavica Pragensia IV. Praha. OCLC 43747593.

VACHEK, J. 1986. Some Remarks on English Loans in Czech Sports Terminology. In: English in Contact with Other Languages. Budapest. ISBN 9630541963.

CAMBRIDGE DICTIONARY. Available online: https://dictionary.cambridge.org/

COLLINS ONLINE DICTIONARY. Available online: https://www.collinsdictionary.com/

OXFORD LEARNERS' DICTIONARIES. 2018. Available online: https://www.oxfordlearnersdictionaries.com/

Words: 4575

Characters: 31448 (17,47 standard pages)

PhDr. Gabriela Entlova, PhD.

Prof. PhDr. Eva Mala, CSc.

Department of English Language Teaching

Faculty of Education

Ostrava University

Fr. Sramka 3

70900 Ostrava

Czech Republic

gabriela.entlova@osu.cz

eva.mala@osu.cz 